\title{
DIVIDEND ARISTOCRATS - A COMPARATIVE ANALYSIS OF POLISH AND AMERICAN DIVIDEND COMPANIES DURING THE PERIOD OF 2009-2017
}

\author{
Bartłomiej Jabłoński, Ph.D. Eng \\ University of Economics in Katowice \\ College of Finance \\ Department of Investment \\ 1 Maja 50, 40-287 Katowice, Poland \\ e-mail: bartlomiej.jablonski@ue.katowice.pl \\ ORCID: 0000-0002-9398-017X
}

Received 10 December 2018, Accepted 24 March 2020

\begin{abstract}
Research background: This article describes the issue of dividend companies that are components of the WIG index and S\&P 500 during the period 2009-2017.

Purpose: The aim of the study was to identify similarities and differences in dividend payments by issuers during the period 2009-2017.

Research methodology: It describes the assessment of investments in companies on the basis of the continuity and variability of dividends paid (taking into account the rate of dividend growth and the cumulated rate of dividends, statistical measures - median and standard deviation), as well as the comparison of issuers from the Polish and US stock exchange.

Results: The results of the study confirm the existence of differences in dividend pay-outs by companies listed on both exchanges.

Novelty: First of all, Polish dividend companies are characterised by a higher average annual dividend growth rate and an average annual rate of return. What is more important, the average accumulated dividend (as well as its median) of companies from the WIG index is higher than the same group of companies belonging not only to the S\&P 500 index companies, but also to American dividend aristocrats.
\end{abstract}

Keywords: dividend companies, dividend aristocrats, dividend, investor

JEL classification: G11, G30, G35, G41 


\section{Introduction}

Investors placing funds in the capital market use tools of fundamental, portfolio or technical analysis. They strive to increase the value of their portfolios of financial instruments through the chosen strategies. Risk diversification can be effected through investments in the securities of different types of benefit and risk level (most common stocks and bonds), as well as it can be carried out within selected groups of securities (e.g. the shares of large, medium and small companies, shares of domestic and foreign companies, shares of companies established in selected geographical areas, or similar bonds of domestic and foreign issuers, government bonds, and municipal or corporate). In view of the long-term investments, most of the stocks of domestic or foreign companies predominate in the portfolios of securities. They generate uncertain and variable incomes - a possible return on the disposal of shares and the possible dividend income paid for the duration of ownership of shares in the portfolio. Among the many listed companies, there are those ones that pay systematic dividends generating a fixed annual income for the investor. They belong to a group of companies known as dividend companies or dividend aristocrats. However, depending on whether the investor will be resident or nonresident from the point of view of legal and tax provisions, the dividend benefit will vary significantly if, in assessing the attractiveness of the investment in the company, the dividend indicators will be taken into account.

The article refers to the theme of dividend companies listed on the stock exchange in Poland and the USA. The purpose of the article is to benchmark the issuers quoted in both markets, taking into account only the dividend companies and the similarities and differences between those issuers for dividend payments during the period 2009-2017. The findings are intended to verify the accepted hypothesis of the similarity between the dividend companies that are the WIG index components and the S\&P 500.

\section{The importance of dividends to capital market investors}

Companies listed on stock exchanges achieved in the accounting year may divide the profit into a part which should remain in the entity for its further reinvestment (or other use) and the part that may be transferred to shareholders in the form of dividends. Therefore, the positive result generated by the company may be transferred to the company's capital increase, capital injection, reserve or special funds, rewards and bonuses for employees and dividend payments. The history of the company's management activities in terms of the systematic payment of dividends, their change or worse, the cessation of payments is the subject of analysis 
by those investors who particularly expect a steady income from dividends. Therefore, in the case of dividend companies, the systematic pay out of dividends is an additional source for the investor, which, apart from being consumed, can be transferred to an increase in the number of shares in the portfolio in particular when the capital market is experiencing a difficult period and stock prices are characterised by significant undervalue. It is worth noting, however, that the company is not obligated to pay dividends. For investors with a potential for reinvestment of dividends, the absence of dividends or the cessation of their payment by the company, is a clear signal of the unattractiveness of such an issuer. ${ }^{1}$ Moreover, the reinvesting process can positively influence the company's assessment by other groups of investors, which does not point out whether the company pays dividends on a regular basis. In the case of reinvestment of the retained profit in economically justifiable projects, it will increase its ability to generate higher profits in the future, thus increasing the EPS ${ }^{2}$ of the company. The history of the changes in dividend pay-outs by stock market issuers and related investor decisions has allowed us to recognise patterns of their behaviour and react to the start, change or cessation of dividend payments by companies. In the literature of the subject (e.g. Cwynar et al., 2007; Kowerski, 2011) it is indicated that the investor's income in the form of the expected dividend is more important than the expected profit on the sale of shares because the dividend is certain whereas possible profits from the price increase actions are uncertain. Investors choose companies that pay dividends at the same time, abandoning investment in such shares, for which they cannot rely on a systematic distribution of the financial result (sparrow theory in handfuls). It should be added that the certainty of dividend payment relates to dividend companies with a clear history of dividend payment. Also, the decisions of the management of the planned dividends are responsible for the increase in share prices and its decline or non-disbursement results in an analogous reverse reaction among investors - the share sale and thus the decline in share prices (signalling effect). In addition, the company which pays dividends without interruption on the basis of the adopted dividend policy attracts specific groups of investors, in particular those who prefer receiving dividends (the customer effect). It is also worth noting that the payment of dividends ${ }^{3}$ is important from the point of view of the re-term of the board. The board of directors recommending the payment of dividends in an uninterrupted manner will raise the votes of those shareholders who are counting on the further withdrawal. Studies conducted by S. Desmukh, A.M. Goel and. K.M. Howe (2013) shows that the over-confident CEOs

\footnotetext{
1 This does not mean that in terms of other parameters of fundamental or technical analysis the company is not attractive to investors.

2 EPS - earnings per share.

3 The fact that dividends will be paid on an unchanging level in the long run, or increasing, is already omitted.
} 
of companies pay lower dividends than rational governors. In turn, excessive self-confidence is characterised by the CEOs of these companies, which are characterised by lower growth rates and lower cash flows. According to B. Graham (2007, p. 447; 1999, p. 297) in the past, dividend policy has been a frequent subject of disputes between public or minority shareholders and the management board.

In general, the shareholders wanted to obtain bigger dividends while the board preferred to hold profits in their hands to "strengthen the company". There has always been a theoretical possibility to re-invest profits in the company; the withholding of funds could be spent on production or increasing revenue. There are, however, several strong arguments against them, such as:

- profits "belong" to shareholders who are entitled to payment within the limits of prudent management,

- for many shareholders, dividend profits are a form of maintenance and in this case "real money", while held in a company, may no longer have such tangible value.

M. Skousen (2011, p. 151) points out that regular dividend pay-outs are a form of pressure on a company to focus on projects that are likely to become a success, because for such a company the worst thing that can happen is a decline in the pay out dividend or total suspension. The studies carried out by D.J. Skinner and E.F. Soltes (2011) show that the likelihood of loss by the company paying the dividends is low and their eventual occurrence is "incidental". In addition, the authors noted that the financial results generated by the dividend companies are more stable than the profits of the other companies and the trend persists over a long period of time. According to B. Graham (2006, p. 449), shareholders should require their boards to have both a normal payment of profits - in a relationship, say, two-thirds - as well as concrete evidence that reinvested profits have led to an increase in the per-share income. Often companies adopt scarce policies because their financial position is weak and need all or most of their profits (and depreciation costs) to repay debts and improve working capital. When this happens, shareholders have little to say, in addition to criticizing the board that it has allowed the company to fall under such a satisfactory financial situation. M. Skousen (2011, p. 142) indicates that more and more evidence shows that companies paying regular dividends have better long-term and lower-risk performance than non-paying dividends, aimed at rapid growth. Recent scientific research shows that a company's indices associated with stocks paying dividends have better results than analogous indices related to market cap value.

According to M. Lichtenfeld (2015, p. 63), the average annual rate of return of the dividend aristocrats S\&P for the period 2001-2011 was 7.1\% while the index of S\&P 500 generated 
only $2.9 \%$ of the average annual rate of return at that time. Additionally, the standard deviation of dividend aristocrats was $18.4 \%$ and was lower, from the same parameter calculated for the S\&P 500 index at 21.3\%. A. Williams and M. Miller (2013, pp. 58-69) concluded that during the financial market crisis in the USA (year 2001 and 2008), the rates of return of companies belonging to the group of dividend aristocrats were characterised by a higher rate of return on the S\&P index. 500. Also, according to M. Skousen (2011, p. 146), dividend-paying shares achieve better financial results from shares not paid for. In addition, the former behave much less chimerically. This is the nature of large companies paying regular dividends. It is worth noting that the payment of stable dividends can not only be allowed by big players, but also internationally active. By functioning in a number of markets, such a company can reduce the volatility of financial results and thus pay more predictable and stable dividends. A bad opinion from the point of view of the stability of dividends are those of companies that are characterised by high the variability of results, which translates into the unpredictability of future dividends. This is confirmed by the study carried out by H. Rubin and C. Spaht II (2011, pp. 11-19). The authors indicate that the growing dividends received by investors constitute an excellent hedge against the decline in the value of the securities portfolios. In developed capital markets, investors analyse the degree of attractiveness of their capital deposits based on the amount of dividends paid and the regularity of its payment (Dębski, 2014, p. 212). A study by K.P. Fuller and M.A. Goldstein (2011, pp. 457-473) confirm that differences in the behaviour of the share rates are seen particularly during a slump period. In addition, P. Asquith and DV Mullins Jr. (1983, pp. 77-96) indicate that, in the case of investment in company dividends, it is important for investors to continuously pay growing dividends. This ensures that the shares of these entities are characterised by long-term stable quotations. Moreover, on the basis of a study by international entities carried out by B. Jabłoński (Jabłoński, Prymon, 2017, p. 71), it can be concluded that dividend companies pay shareholders for the longer-term nature of their investments. Selected issuers reward long-term shareholders (usually the minimum of a twoyear share-holding) an additional dividend and, in particular, the American and French markets introduce automatic dividend reinvestment schemes (DRIP - dividend reinvestment program) in the shares of the company that pays the dividend.

The attractiveness of investments in dividends is determined not only by the amount or the distribution of dividends, but also by the place of payment of taxes on dividends received, exchange risk and the amount of commission transaction. What will be the final rate of return on the investment in a dividend company and the net amount of dividends earned may be reinvested depends on whether it is resident or non-resident in accordance with the tax laws. A natural 
person who receives a payment from the profits of a Polish company does not include the dividend tax in the annual return. However, dividends received from a company listed on the foreign market (and established there) should have the tax flat PIT at 19\%, with the obligation to deduct the tax paid abroad. It is important that the deduction cannot exceed the amount of tax paid in Poland. On this basis, it can be concluded that, where the tax levied abroad is higher than that paid by the taxable person in Poland, the investor is not obliged to pay the difference in both taxes. However, if the tax deducted from a foreign company collected abroad is lower than the flat tax in Poland, the investor is obliged to pay the difference in this tax. Depending on the tax laws of the country in which the investor obtains dividends, an imbalance in the taxation of dividends can significantly and negatively affect the profitability of long-term investments. Any higher dividends paid by foreign companies can be significantly reduced by tax liabilities. ${ }^{4}$ Therefore, non-residents investing capital outside the country in which they settle should not, in their investment decisions, disregard the fact that the tax burden is unfavourable. The investment profitability account is also worth taking into account with the differences in commission on investments in domestic and foreign companies. Often, in the case of the latter, transaction commissions differ significantly in favour of investments in domestic companies. It is also not possible to design the exchange risk issue. A high rate of return on investment in foreign currency companies can be significantly reduced by unfavourable exchange rate changes.

\section{Research on Polish and American dividend companies - a comparative analysis}

The assessment of the attractiveness of investment in the shares of companies can be based on a number of factors and models. The solutions presented in the literature often take into account the criteria that the investor is unable to identify quickly, which significantly limits the ability to apply them in practice. In addition, obtaining detailed information from the company, if they are one of the criteria for the selection of shares in the portfolio, in the case of companies with limited investor information policy, is impossible. As an example, the criteria for success and a company's working force (model Barra International), company size, income rates and the popularity factor (Dowen model, Bauman) or the Goldmach Sachs \& Co. model which,

\footnotetext{
${ }^{4}$ An example would be investments in American dividend companies. Despite the signing between the Polish and US agreements on the avoidance of double taxation, a tax of $30 \%$ is levied on the source of dividends (the US capital market and its issuers). The difference in the taxation of dividends received will be even greater if the investor takes into account the tax benefits of the pension scheme (IKE or IKZE). In accordance with the regulations in force in Poland, a natural person investing in these programs in companies established in Poland does not pay a tax of $19 \%$. Therefore, thanks to the selected tax solutions, investments in dividend companies quoted in Poland may have a higher tax advantage on dividends received e.g. from companies listed in the USA.
} 
as guidelines for the selection of shares, indicate including cash flow rate, debt increase, risk price and company size (Trzaskalik, 2006, p. 104). From this point of view, dividends and market dividends, as the basic criteria for the selection of shares - taking into account in their construction changes in dividends paid, share prices or accumulated dividends are not only easier to rapidly use, but also because of its construction possible to apply irrespective of the quality of the company's communication with capital market investors. A survey of Polish and American dividend companies was carried out on 30.09.2018, which was the subject of the study, which was assigned to the group of dividend companies for a comparative analysis. From among the 459 Polish issuers listed on the primary market (WIG index) and the New Connect market were selected those which paid out dividends over a period of 10 years (payments during the period 2009-2017 for the period 2008-2016). In turn, among the American companies that are S\&P index components, 500 companies were marked and characterised as aristocrats' dividends. So as to introduce this comparative analysis the same number of American dividend aristocrats were marked, starting from those ones which belong to the index S\&P 500 Dividend Aristocrats for the longest period of time. For the purposes of this study, the following hypotheses were accepted:

$\mathrm{H}_{0}$ : WIG Index component companies (Poland), which paid dividends without interruption during the period 2009-2017 are characterised by a higher average annual rate of dividend growth from dividend companies from the S\&P 500 (USA) index for the same period

and

$\mathrm{H}_{1}$ : There are no companies of the WIG index components, which paid the dividends without interruption during the period 2009-2017 and are characterised by a higher average annual growth rate of dividends from dividend companies from the S\&P 500 (US) index for the same period.

The purpose of the research among listed companies in the Warsaw Stock Exchange was to mark those which during the period 2009-2017 paid dividends without interruption (state on 20.09.2018). In this way 15 companies were marked. The number of companies paying dividends increases with the reduction of a company selection criteria. By changing the number of payment periods for dividends up to 9 years, the number of companies grows to 24 , whereby dividends are understood to be those that pay uninterrupted dividends (Figure 1). 


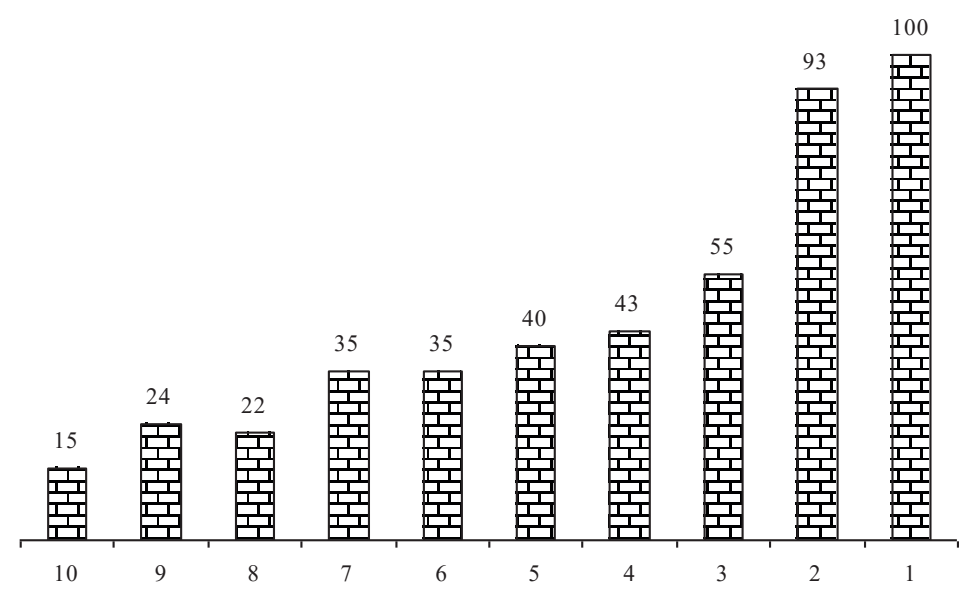

Figure 1. Number of companies that are components of the WIG index, which paid dividends with varying frequencies during the period 2009-2017

Source: own study.

The chart shows that if, in subsequent periods of the company, the dividends are to be paid continuously, the number of companies paying dividends without interruption for a period of 10 years will increase or be exacerbated by the selection criterion of the dividend companies. The number of dividend companies for a longer period (2000-2017) is presented in Figure 2.

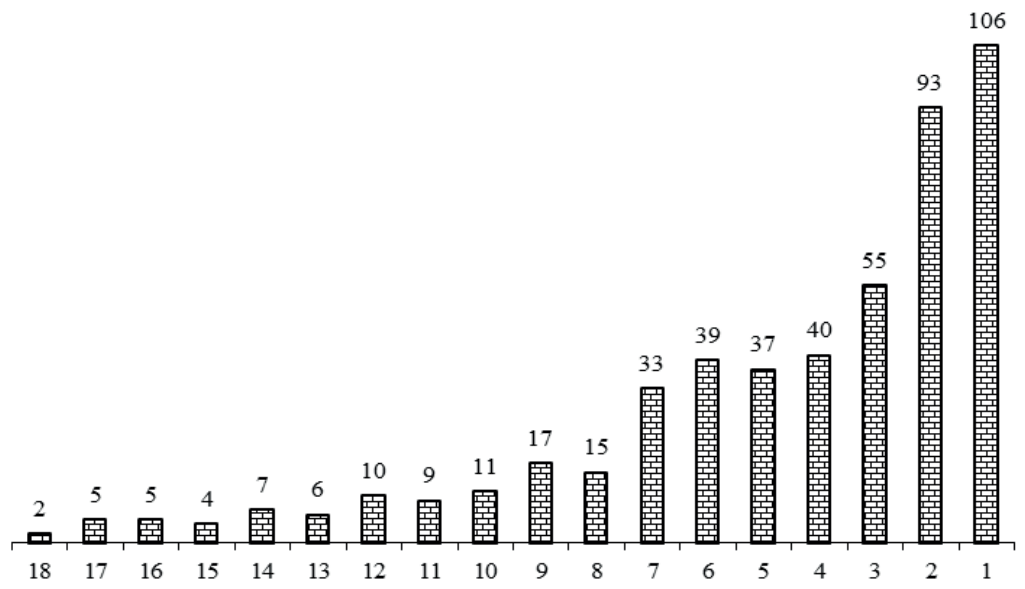

Figure 2. Number of companies that are components of the WIG index, which paid dividends for the period 2000-2017

Source: own study. 
It is worth noting that there are two companies which paid dividends without interruption (Apator, Stalprofil) for the period 2000-2017. It is also apparent from the data provided in diagram 1 and 2 that, should account for periods without payment of dividends (in different variants) of companies classified for research from 2000, it would be much more. In turn, the second group of companies was among the dividend aristocrats coming from the S\&P 500 (US market) index. The agency Standard \& Poor's company specifies as a dividend aristocrat, ${ }^{5}$ if it belongs to the S\&P 500 index and at the same time over the last 25 years each year has increased the amount of dividend paid, on the day of index updates its capitalisation is at least 3 billion dollars and for the six months preceding the index update, the trading of the company amounted to an average of $\$ 5$ million a day. The number of dividend aristocrats quoted in the US for a comparable period (2008-2017) is presented in Figure 3.

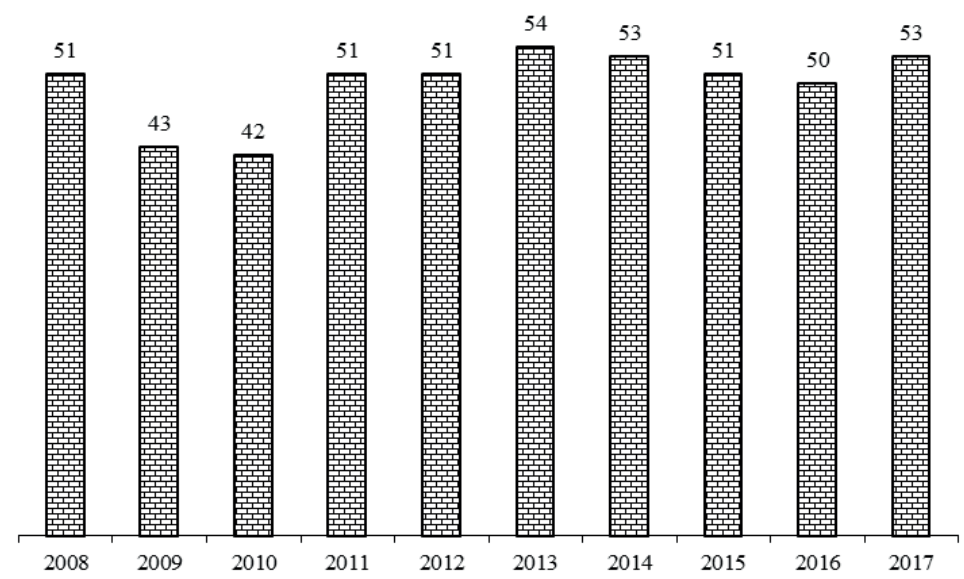

Figure 3. Number of dividend aristocrats being components of the S\&P 500 index for the period 2008-2017

Source: own study.

The data presented in Figure 3 shows that a stable number of dividend aristocrats have been maintained since 2008 and it has not fallen below 40 companies (only for 2 years the number was lower than 50 companies - 2009 and 2010 years). For the purposes of research to preserve a comparable number of companies, among 53 American dividend aristocrats indicated on the day of the survey 15 entities had been marked; those were the ones that paid dividends without interruption for the longest period. For both groups of dividend companies, the average annual rate of dividend growth, the median annual dividend growth rate, the sum of dividends

\footnotetext{
5 S\&P 500 Dividend Aristocrats.
} 
paid the average annual rate of return and the cumulative dividend yield (Tables 1 and 2) were calculated.

Table 1. Parameters of dividend Companies (WIG)

\begin{tabular}{|c|c|c|c|c|c|}
\hline Issuer name & $\begin{array}{l}\text { Average annual } \\
\text { dividend growth } \\
\text { rate }(\%)\end{array}$ & $\begin{array}{l}\text { Median annual } \\
\text { dividend growth } \\
\text { rate }(\%)\end{array}$ & $\begin{array}{c}\text { Total paid } \\
\text { dividends } \\
(\mathrm{PLN})\end{array}$ & $\begin{array}{l}\text { Average annual } \\
\text { return rate } \\
(\%)\end{array}$ & $\begin{array}{c}\text { Cumulated } \\
\text { dividend rate } \\
(\%)\end{array}$ \\
\hline Apator & 33.48 & 22.50 & 6.70 & 28.42 & 91.41 \\
\hline AssecoPol & 15.01 & 10.79 & 20.42 & 4.12 & 68.20 \\
\hline ATMGrupa & 131.41 & 16.67 & 2.07 & 4.47 & 68.77 \\
\hline Budimex & 31.21 & 27.02 & 78.17 & 75.99 & 319.06 \\
\hline DomDev & 35.80 & 28.47 & 20.43 & 57.79 & 162.66 \\
\hline Eurcash & 44.92 & 0.00 & 5.43 & 23.35 & 65.58 \\
\hline Eurotel & 11.23 & 14.64 & 12.89 & 47.45 & 317.49 \\
\hline Kruszwica & 297.44 & 7.52 & 28.86 & 16.22 & 103.96 \\
\hline Neuca & 15.30 & 15.00 & 30.83 & 77.00 & 93.17 \\
\hline Pulawy & 51.40 & 29.89 & 60.62 & 36.51 & 172.61 \\
\hline Sniezka & 14.57 & 3.93 & 20.45 & 38.29 & 126.47 \\
\hline Stalprofi & 19.07 & 4.00 & 1.21 & 15.65 & 20.00 \\
\hline Unibep & 9.50 & 6.67 & 1.20 & 14.99 & 29.48 \\
\hline Wawel & 10.02 & 0.00 & 135.00 & 69.61 & 97.69 \\
\hline Zywiec & 17.49 & 14.68 & 304.00 & 9.98 & 125.93 \\
\hline
\end{tabular}

Source: own study.

Table 2. Parameters of dividend companies (S\&P 500)

\begin{tabular}{|l|c|c|c|c|c|}
\hline \multicolumn{1}{|c|}{ Issuer name } & $\begin{array}{c}\text { Average annual } \\
\text { dividend growth } \\
\text { rate (\%) }\end{array}$ & $\begin{array}{c}\text { Median annual } \\
\text { dividend growth } \\
\text { rate (\%) }\end{array}$ & $\begin{array}{c}\text { Total paid } \\
\text { dividends } \\
\text { (USD) }\end{array}$ & $\begin{array}{c}\text { Average annual } \\
\text { return rate } \\
(\%)\end{array}$ & $\begin{array}{c}\text { Cumulated } \\
\text { dividend rate } \\
(\%)\end{array}$ \\
\hline $3 \mathrm{M}$ & 2 & 3 & 4 & 5 & 6 \\
\hline Cincinnati Fin. & 12.89 & 1.72 & 17.90 & 26.40 & 58.48 \\
\hline Coca-Cola & 0.30 & 6.44 & 13.35 & 16.64 & 74.62 \\
\hline Colgate-Palmolive & 2.26 & 5.56 & 15.54 & 17.49 & 53.94 \\
\hline Dover & 7.54 & 6.36 & 12.78 & 36.49 & 68.20 \\
\hline Emerson Electric & 4.84 & 4.56 & 14.86 & 14.98 & 51.07 \\
\hline $\begin{array}{l}\text { Federal Realty Inv. } \\
\text { Trust }\end{array}$ & 5.34 & 5.24 & 28.58 & 17.74 & 57.27 \\
\hline Genuine Parts & 12.18 & 9.17 & 18.25 & 22.86 & 60.06 \\
\hline Hormel Foods & 0.21 & 2.32 & 6.87 & 47.42 & 100.99 \\
\hline
\end{tabular}




\begin{tabular}{|l|c|c|c|c|c|}
\hline \multicolumn{1}{|c|}{1} & 2 & 3 & 4 & 5 & 6 \\
\hline Johnson\&Johnson & 7.02 & 6.72 & 23.46 & 20.80 & 49.22 \\
\hline Lowe's Companies & 20.22 & 20.61 & 7.15 & 43.17 & 38.09 \\
\hline Procter\&Gamble & 6.02 & 7.02 & 20.81 & 9.40 & 42.92 \\
\hline $\begin{array}{l}\text { Stanley Black } \\
\text { \& Decker }\end{array}$ & 8.23 & 6.34 & 16.92 & 52.25 & 57.61 \\
\hline Sysco & 5.03 & 3.88 & 9.88 & 24.88 & 53.61 \\
\hline Target & 19.00 & 20.13 & 13.76 & 14.49 & 49.80 \\
\hline
\end{tabular}

Source: own study.

Irrespective of the measure adopted for the comparison of the two groups of companies, the average annual dividend growth rate and the median annual growth rate of this indicator are more favourable for companies that are components of the WIG index (Figure 4).

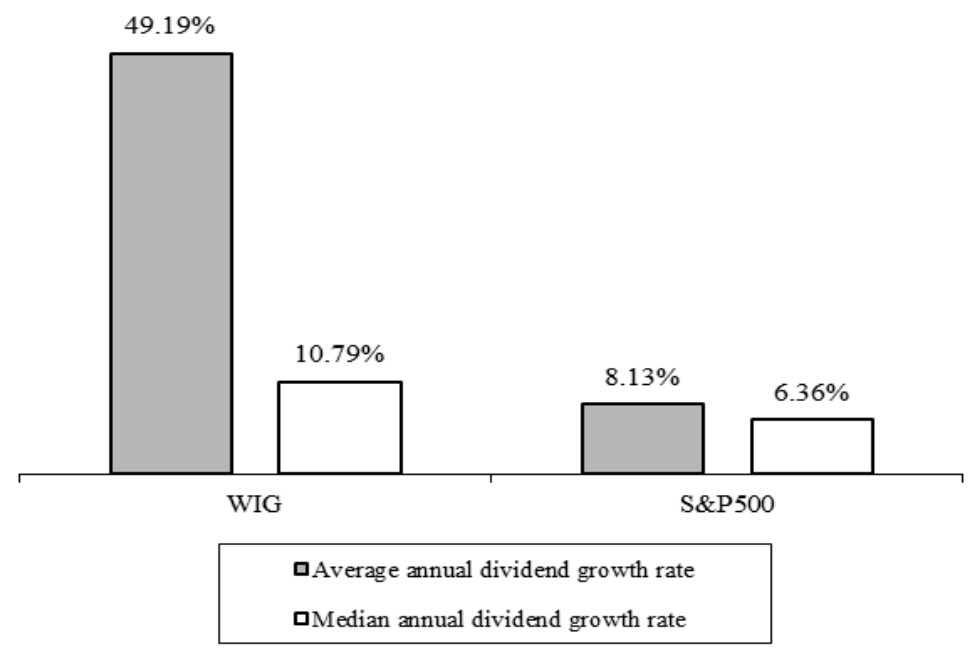

Figure 4. The annual rate of dividend growth for dividend companies from the WIG Index and S\&P 500

Source: own study.

Stable readings (over the years) of the growth rate of the dividend combined with the dividend rate above the industry average or dividend companies quoted on a particular stock exchange are characterized by valuable dividend companies that the investor Looking not only for developed but also developing capital markets. It is worth paying attention to the trap of high rate of dividend growth (g). Any longer maintenance of a high rate of increase in the payment of dividends without being confirmed in the company's financial results may result in 
a reduction in future dividends (negative dynamics of change) or at least a significant reduction in the G parameter value. Therefore, in particular, the companies in the S\&P 500 Dividend Aristocrats are paying dividends with a stable growth rate of exceeding by several percentage points of inflation, although they could increase the rate of change in dividends. This is confirmed by the results of the studies carried out-the level of $8.13 \%$ of the average annual dividend growth rate compared to $49.19 \%$ for the Polish market. Even after removing two companies from the Polish market (ATM Group and Kruszwica) with a high reading of parameter G, the average annual dividend growth rate for group 13 companies from the WIG index is $23.77 \%$ (median $14.64 \%)$

The American dividend pay-outs are characterized by a lower parameter $(\mathrm{g})$ due to the concerns of the inability to maintain high readings of this parameter and the negative investor's perception of such decisions. The average annual rate of return of both company groups and the median of their annual return rate (Figure 5) are even more attractive to Polish dividend companies.

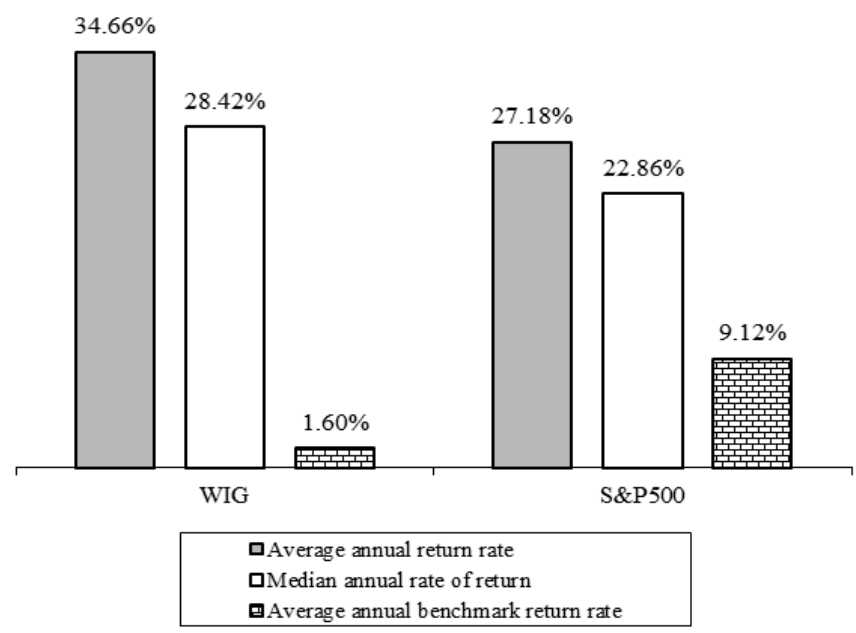

Figure 5. The measure of the annual rate of return of dividend companies from the WIG Index and S\&P 500

Source: own study.

The studies show that not only the average annual rate of return and the median annual rate of return of Polish dividend companies are higher than the American dividends, but both groups of companies have higher parameters than those adopted Benchmarks (for Polish companies, this is the average annual rate of return of the WIG index for the American market, 
the annual average rate of return of index S\&P 500). The biggest surprise, however, is the greater difference in the average rate of return of Polish dividend companies (34.66\%) against the adopted benchmark for the Polish market (1.6\%) compared with the American market, respectively 27.18 and $9.12 \%$.

It is also apparent from the studies that the S\&P 500 index was characterised by a higher average rate of return for the period considered, which would make it easier for companies in this index to maintain a high rate of increase in quotation prices. Despite this fact, Polish dividend companies fall in this comparison much better. Also irrespective of the measure of the cumulated dividend rate for the companies investigated, the market for Polish dividend companies is much better (Figure 6).

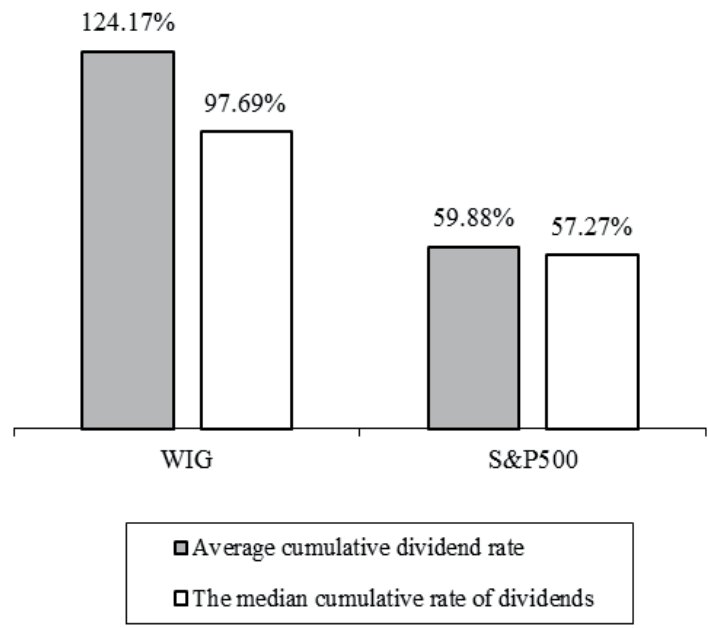

Figure 6. The measurement of the cumulated dividend rate of dividend companies from the Polish and American market

Source: own study.

For the purpose of evaluating the company after a long-term holding of shares in the portfolio, investors can use the ratio of the cumulated dividend rate. The benchmark does not include quotation prices, as is the case with the traditional calculation of the dividend rate (DY), but the level of acquisition of shares (or, for several investments in shares in the company, the average price of shares).

The DY change allows the tracking of the increase in dividends paid in relation to the level of investment in shares and exceeding the level of $100 \%$ means that the sum of dividends 
received exceeded the level of investment. ${ }^{6}$ The cumulative rate of dividends is calculated according to the formula:

$$
D Y_{S}=\frac{\sum_{t=1}^{n} D P S_{t}}{P_{t}} \times 100 \%
$$

where:

$D P S_{t}$ - dividend per share received by the investor in year $t$,

$P_{t} \quad-$ price of the acquisition of shares

A comparison of the characteristics of dividend payment and price changes of Polish and American dividend companies is presented in Table 3.

Table 3. Parameters of dividend companies from the WIG index and S\&P 500 (\%)

\begin{tabular}{|l|c|c|}
\hline \multicolumn{1}{|c|}{ Company parameters } & WIG & S\&P500 \\
\hline Average annual dividend growth rate & 49.19 & 8.13 \\
\hline Median annual dividend growth rate & 10.79 & 6.36 \\
\hline Average annual return rate & 34.66 & 27.18 \\
\hline Median annual rate of return & 28.42 & 9.12 \\
\hline Average annual benchmark return rate & 1.60 & 59.88 \\
\hline Average cumulative dividend rate & 124.17 & 57.27 \\
\hline The median cumulative rate of dividends & 97.69 & 12.91 \\
\hline Standard deviation of annual dividend growth rates & 113.59 & \\
\hline
\end{tabular}

Source: own study.

In summary, a comparison of the Polish and American dividend companies recognises an appreciably higher volatility in dividends paid and based on the standard deviation of annual dividend growth rates. With an average annual dividend growth rate of $49.19 \%$ for a WIG company, the standard deviation is $113.59 \%$. The same parameters for companies from the S\&P 500 index are $8.13 \%$ and $12.91 \%$ respectively.

\footnotetext{
${ }^{6}$ It is worth noting that such a reading is not achievable in the case of the traditional DY rate for normal market conditions, since the price of shares after the cut-off of the right to dividend would have to be adjusted to level 0 .
} 


\section{Conclusions}

In the article, the use of market indicators based on dividends paid by companies, not only confirmed their applicability in the comparative analysis, but also showed the importance of dividend companies. These indicators are relatively easy to calculate, update and interpret by which they can be successfully applied by capital market investors. Based on the studies conducted by Polish and American dividend companies, the accepted hypothesis $\mathrm{H}_{0}$ : The companies which are the WIG index components (Poland), which paid dividends uninterruptedly during the period 2009-2017 are characterised by a significant higher average annual dividend growth rate from dividend companies from the S\&P 500 index (US) for the same period. Moreover, on the background of American dividend aristocrats, the dividend companies which are components of the WIG index are characterised by:

1. Higher median annual dividend growth rate.

2. Higher average annual rate of return (also from the adopted benchmark).

3. A higher median annual return rate.

4. Higher average cumulative dividend rate (also the median of this parameter).

On the basis of the studies, however, it is noted that, in the case of Polish dividend companies, there is a significantly higher volatility in dividends paid on the basis of the standard deviation of annual dividend growth rates. This should not be surprising, however, because of the large difference in the average annual dividend growth rate. Thus, it can be concluded that dividends on the stock exchange are attractive from similar companies listed on the American market. In fact, companies that are components of the S\&P 500 index and classified as a group of dividend aristocrats are characterised by a lesser volatility in the level of dividends paid and a lower average annual rate of return. On the basis of the studies, it can be concluded that despite the shorter history of dividends being paid by dividend companies listed on the Warsaw Stock Exchange, they are characterised by better parameters, which are in particular analysed by capital market investors who pay attention to long-term investments and reinvestment of the dividends they receive. The analysis of the study also indicates the possibility of naming the already Polish dividend companies as dividend aristocrats, in particular if the practice of dividend payment will be maintained over time.

It is also significant to emphasize the importance of having a dividend policy which is properly constructed, described and manifested. However, it remains open to keep these companies in a longer period of time such a high average annual growth rate of dividends. 


\section{References}

Asquith, P., Mullins, Jr D.W. (1983). The Impact of Initiating Dividend Payment on Shareholders' Wealth. Journal of Business, 56 (1), 77-96.

Cwynar, A., Cwynar, W. (2007). Kreowanie wartości spółki poprzez dtugoterminowe decyzje finansowe. Warszawa: Wydawnictwo Wyższej Szkoły Informatyki i Zarządzania.

Desmukh, S., Goel, A.M., Howe, K.M. (2013). CEO Overconfidence and Dividend Policy. Journal of Financial. Retrieved from: https://ssrn.com/abstract=1496404 (12.09.2018).

Dębski, W. (2014). Rynek finansowy i jego mechanizmy. Podstawy teorii i praktyki. Warszawa: Wydawnictwo Naukowe PWN.

Fuller, K.P., Goldstein, M.A. (2011). Do Dividends Matter More in Declining Markets? Journal of Corporate Finance, 17 (3), 457-473.

Graham, B. (1999). Mądry inwestor. Kraków: Wydawnictwo Profesjonalnej Szkoły Biznesu.

Graham, B. (2007). Inteligentny inwestor. Warszawa: Wydawnictwo Studio EMKA.

Jabłoński, B., Prymon, K. (2017). Polityka dywidend współczesnego przedsiębiorstwa - teoria i praktyka. Katowice: Wydawnictwo Uniwersytetu Ekonomicznego w Katowicach.

Kowerski, M. (2011). Ekonomiczne uwarunkowania decyzji o wypłatach dywidend przez spółki publiczne. Kraków-Rzeszów-Zamość: Konsorcjum Akademickie Wydawnictwo WSE w Krakowie, WSIiZ w Rzeszowie i WSZiA w Zamościu.

Lichtenfeld, M. (2015). Get Rich with Dividends. New Jersey: John Wiley\&Sons, Inc.

Rubin, H., Spaht II, C. (2011). Financial Independence Through Dollar Cost Averaging and Dividends Reinvestment. Journal of Applied Business and Economics, 4, 11-19.

Skinner, D.J., Soltes, E.F. (2011). What Do Dividends Tell Us About Earnings Quality? Review of Accounting Studies, 16 (1).

Skousen, M. (2011). Inwestowanie w jednej lekcji. Warszawa: Fijorr Publishing Company.

Trzaskalik, T. (2006). Metody wielokryterialne na polskim rynku finansowym. Warszawa: PWE.

Williams, A., Miller, M. (2013). Do Stocks with Dividends Outperform the Market during Recession. Journal of Accounting and Finance, 13 (1), 58-69. 